\title{
YOUTUBE AS A MEDIA FOR STUDENTS' COMPREHENSIVE LISTENING ABILITY AT JUNIOR HIGH SCHOOLS IN BEKASI
}

\author{
Sigit Widiyarto ${ }^{1}$ Mulyadi $^{2}$, Lusiana Wulansari ${ }^{3}$, Aster Pujaning Ati $^{4}$ \\ 1,2,3,4 Universitas Indraprasta PGRI, Jakarta, Indonesia \\ ${ }^{1}$ sigit.widiyanto372@gmail.com, ${ }^{2}$ mrmulyadi57@gamil.com, ${ }^{3}$ lusiana_ws@yahoo.co.id, ${ }^{4}$ asterpujaningati@gmail.com
}

\begin{abstract}
Learning in the listening aspect is still difficult for middle and upper level students. This is a consequence of weak vocabulary, structure, and speaking skills. Comprehensive listening skills are often complained by some students. It needs improvement and learning innovation in the current century. This study aimed to determine whether there was an increase in learning outcomes after utilizing youtube as a learning media, how big the impact was and how the learning process using you tube media was. This study used an experimental method of pretest and posttest only. Respondents were 35 students of SMP Alikhlas class VI Bekasi. The data were taken from the test before and after being given treatment using YouTube media. The data were processed with SPSS 20 and then tested for normality and homogeneity first, then processed using a paired sample test. The results showed that there was an increase of 12.2941. The use of youtube improved listening skills. Utilizing Youtube included looking for material/information, watching and listening to material, analyzing and distributing material to students and teachers. The recommendation was that teachers could try to provide the widest possible time and space for students to improve their abilities independently, including using YouTube in learning. Consistent evaluation and supervision is the key to the success of learning using youtube media.
\end{abstract}

Keywords: listening, comprehensive, youtube

\section{YOUTUBE SEBAGAI MEDIA UNTUK KEMAMPUAN BELAJAR MENDENGAR KOMPREHENSIF UNTUK SISWA SMP BEKASI CITY}

\begin{abstract}
ABSTRAK
Pembelajaran pada aspek mendengar masih sulit bagi para siswa tingkat menengah dan atas. Hal ini merupakan konsekwensi dai lemahnya kemampuan kosa kata, struktur dan berbicara. Kemampuan mendengar komprehensif sering dikeluhan olah sebagian siswa. Hal ini perlu perbaikan dan inovasi pembelajaran pada abad saat ini. Penelitian ini bertujuan untuk mengetahui apakah ada kenaikan hasil belajar pada penggunaan media youtube, seberapa besar dampaknya dan bagaimana proses pembelajaran dengan menggunakan media you tube. Penelitian ini menggukan metode eksperimen jenis pretest and postes only. Responden sebanyak 35 siswa SMP Alikhlas kelas VI kota Bekasi. Data diambil dari tes sebelum dan sesudah diberikan perlakuan penggunaan media Youtube. Data diolah dengan SPSS 20 lalu diuji normalitas dan Homogenitas terlebih dahulu, setelah itu diolah dengan menggunakan uji sample berpasangan. Hasil penelitian menunjukkan bahwa ada kenaikan sebesar 12.2941. Penggunaan media you tube dapat meningkatkan kemampuan mendengar. Proses pembelajaran media you tube meliputi, mencari materi/informasi, menonton dan mendengarkan materi, menganalisis dan membagikan materi kepada siswa dan guru. Rekomendasi yang dapat diberikan adalah guru dapat berusaha memberikan waktu dan ruang yang seluas-luasnya kepada siswa agar dapat meningkatkan kemampuannya secara mandiri, termasuk menggunakan YouTube dalam pembelajaran. Evaluasi dan supervisi yang konsisten merupakan kunci keberhasilan pembelajaran menggunakan media youtube.
\end{abstract}

Kata Kunci: mendengar, komprehensif, youtube

\begin{tabular}{|c|c|c|}
\hline Submitted & Accepted & Published \\
\hline 11 Agustus 2021 & 30 September 2021 & 24 November 2021 \\
\hline
\end{tabular}

\begin{tabular}{|l|l|r|}
\hline Citation & $:$ & $\begin{array}{r}\text { Widiyarto, S., Mulyadi, M., Wulansari, L., \& Ati, A.P. (2021). Youtube as a Media for Students' Comprehensive Listening } \\
\text { Ability at Junior High Schools Bekasi. Jurnal PAJAR (Pendidikan dan Pengajaran), 5(6), 1699-1706. DOI : } \\
\text { http://dx.doi.org/10.33578/pjr.v5i6.8504. }\end{array}$ \\
\hline
\end{tabular}

\section{INTRODUCTION}

Learning to listen is often a very difficult learning. This is because many students have not gotten used to practicing listening to basic, intermediate and advanced conversations. Learning to listen in class is still not optimal. Many teachers have not prepared listening lessons. Listening is the highest language skill besides writing. This needs special attention for language teachers.

The pattern of teaching listening must be given in sufficient portions so that students do not fall behind. Practice and practice to speak should be a priority scale. In the end the students had difficulties. Students need to be given a suitable 
learning model, so that they can master listening skills.

Several factors cause students to experience problems when learning Listening Comprehension in English, for example, the material is too fast to listen to so they don't remember what they have heard, they don't know the meaning of words in English that are spoken or listened to because of the limited vocabulary that students have., do not concentrate fully on the material being listened to, do not understand verbally explained commands, are lazy in learning or have no motivation to learn, and many other factors.

The researcher highlights on the side of the teaching media that must be modified or at least the teachers have teaching innovations that are in accordance with the current era. Many lessons are less effective, such as teaching in class without adequate tools. Moreover, learning listening comprehension is still considered difficult by students. At the beginning of the researcher's observation at one junior high school, the average listening comprehension score was still below 60 . The next observation was in a state junior high school, the average listening comprehension score, although slightly good, was still in the range of 65 .

Based on this fact, teachers must optimize the use of media learning to create a conducive and interesting learning environment. Learning media as one of the components in learning plays an important role so that learning can take place in accordance with the learning objectives. Therefore, the teacher must also evaluate the use of listening skills learning media in order to find out what obstacles are experienced by students learners to the learning media used, especially for listening.

You Tube has become a cultural force that alters how individuals interact with one another online and offline, and will continue to be a catalyst for social, educational and musical change. YouTube also has been a subject of increasing interest among research-ers in education and psychology (Kruse, N. B., \& Veblen, K. K. : 2012) other info said that the development of YouTube in Indonesia is very fast when compared to other countries in the Asia
Pacific region with an increase in the number of videos uploaded by $600 \%$ in the third quarter of 2015 Basuki ( In Erwin F.A, 2015, p. 1-2)

Learning English must be equipped with adequate vocabulary and sentence structures. Without mastery of vocabulary students will experience difficulties in composing sentences, and at times expressing sentences. When students are able to master vocabulary, but have not mastered adequate sentence structure, students will find it difficult to assemble sentences correctly. So that the relationship between vocabulary and sentence structure is very close, and cannot be separated from one another. Mastery of vocabulary is one of the main requirements that determines the success of an individual to become skilled at language, the richer the individual's vocabulary is, the more likely the individual is to become skilled at language (Rahayu.S, et al: 2018)

The vocabulary ability becomes the foundation for understanding the concept of reading comprehension in English. The students' vocabulary skills can be the basis for assembling sentences correctly. Salah satu kelemahan siswa sulit memahami suatu percakapan dikarena,penguasaan kosa kata ,tata bahasa dan pengucapan yang masih rendah(Widiyarto, S., \& Ati, A. P., : 2018). In the learning process in the teacher's classroom, sometimes they have difficulty teaching vocabulary effectively. The teaching process will take a long time, if the methods used are not interesting and tedious. Students sometimes mispronounce vocabulary, this could be understood, because teaching pronunciation is also constrained by the lack of reading practice, plus low reading interest.

The teachers have used a lot of other learning tools, methods and learning resources, including You tube, because YouTube is increasingly being used by educators as a pedagogic resource for everything from newsworthy events from around the world to "slice-of-life" videos used to teach students within an ESL (English as a Second Language) course (Duffy, P. : 2008). However, it is necessary to pay attention to the conditions and situations in the classroom, because each class and region has different characteristics. For example, learning in 
cities and villages, of course, is very different and can be a separate consideration, before using a tool and method in class.

Learning methods in the classroom can be an impact on the results of students' skill levels. Methods that are in accordance with students' abilities will encourage student learning success, especially learning vocabulary. Giving exercises and explanations from the teacher is very important. Because students will feel confused, if students are not given examples and explanations of how to read and pronounce vocabulary.

Mastery of vocabulary is still an obstacle for class X Al Ikhlas high school students. The minimum completeness criteria are still below 75 . The average daily test score was 74 . Students are not optimally studying in class. This makes students less enthusiastic about learning. English teachers have not explored classroom learning. This is obtained after the teacher reveals the learning constraints in class.

The use of media is very necessary. The use of media can be a learning aid, so that students learn with enthusiasm in class, and can reduce boredom. Among the learning media that can be used in class is scrabbled. This media can be used and is well known as a game among students. The use of this game is very simple, students can use English and fill in the scores they get. This media can help students interact (Sunarmintyastuti, L, et al: 2020). Efforts to learn Indonesian language skills continue. One of them is by diversifying learning media in the classroom (Widiyarto.S, et al: 2017)

Based on the description above, the problems and objectives of this research can be described, as follows, first, whether you tube media can improve students' listening comprehension learning outcomes, whether there is an impact of you tube media in listening corehension learning and how the you tube media learning process for students. Meanwhile, the purpose of the research is to find out whether you tube media can improve listening comprehension learning, how much impact you tube learning has on and how you tube media learning process.

\section{LITERATURE REVIEW YouTube}

In essence, YouTube is a web address that helps users share videos and can use these videos as entertainment. The video can be uploaded by various people. The types of videos that can be uploaded are film videos, video clips, short films, educational videos and others.

The first youtube features are autoplay, which is a type of feature that is useful for playing the next video automatically, without choosing which video to play, the second annotation, this is a web address in the form of a video or box whose position is in the video being played, the third setting video speed, this feature is useful for slowing down and accelerating the video film that is currently playing, the four subtitles, which are features that are made so that we understand the meaning and words in the video, the fifth is download, this feature serves as a tool to download movies that we will watch offline .

\section{Media}

The word media comes from the word medium which means intermediary. Media can be interpreted as a recipient of information, or a source of information for people who receive it. In the teaching and learning process, the media can function as a bridge. This process will be effective and efficient when students can receive messages or information given by the teacher. The process can be illustrated in Figure 1 below:

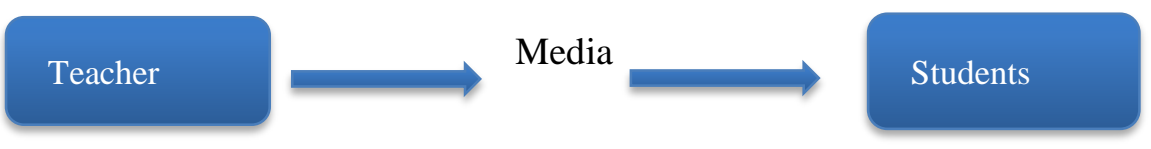

Figure 1.The learning process Of Teacher and Student

\section{Listening Comprehension}

Listening for the purpose of understanding is called comprehensive listening. A person can be said to be a good comprehensive listener if he is able to receive, pay attention, and give the 
meaning of the message as close as possible to the message conveyed by the speaker.

Listening is a process that includes listening to the sounds of language, identifying, interpreting, assessing, and reacting to the meaning contained in it. Listening involves hearing, seeing, experiencing, remembering, understanding. Even the situation that accompanies the sound of the language being listened to must be taken into account in determining its meaning. Mendengar untuk tujuan memahami disebut menyimak komprehensif.

\section{REASERCH METHOD}

A research method used to find the effect of certain treatments on others under controlled conditions. the experiment was actually carried out. This study used a pretest-posttest control group design. This design uses a pretest, before being given treatment and given a posttest after being given treatment. This is done in order to know, the effect of the treatment with certainty. The data is in the form of test results. Students who became respondents were 35 students of SMP VII Alikhlas class, Bekasi city. The selection of respondents was random. The research was conducted in early January to May 2021.

Data collection techniques include interviews, giving tests before and after treatment, and documentation. The data analysis technique uses assumption test (classic), including homogeneity and normality tests. The data was then processed by using a paired data sample test.

Researchers can control all external variables that affect the course of the experiment, thus the internal validity or quality of the implementation of the research design can be relied upon (Sugiyono, 2017, p. 112). This design is divided into Posttest-Only Control Design, and Pretest-posttest Control Group design.

Table 1. Research Plan

\begin{tabular}{ccc}
\hline $\mathrm{T} 1$ & $\mathrm{X}$ & $\mathrm{T} 2$ \\
\hline Pretest & Treatmen & Postest \\
\hline
\end{tabular}

Information :

$\mathrm{T} 1=$ Initial test is given to the experimental class at the beginning of the study

$\mathrm{X}=$ Given treatment in the experimental class (learning using You Tube)

$\mathrm{T} 2=$ The final test is given to the experimental class after being given treatment :

\section{RESULTS AND DISCUSSION}

Data processing is carried out in stages. Pretest and posttest data were processed by normality test and homogeneity test. This is done to analyze whether the data to be processed is normally distributed and the homogeneity test is fulfilled. The treatment process using you tube follows the steps in the picture as follows:

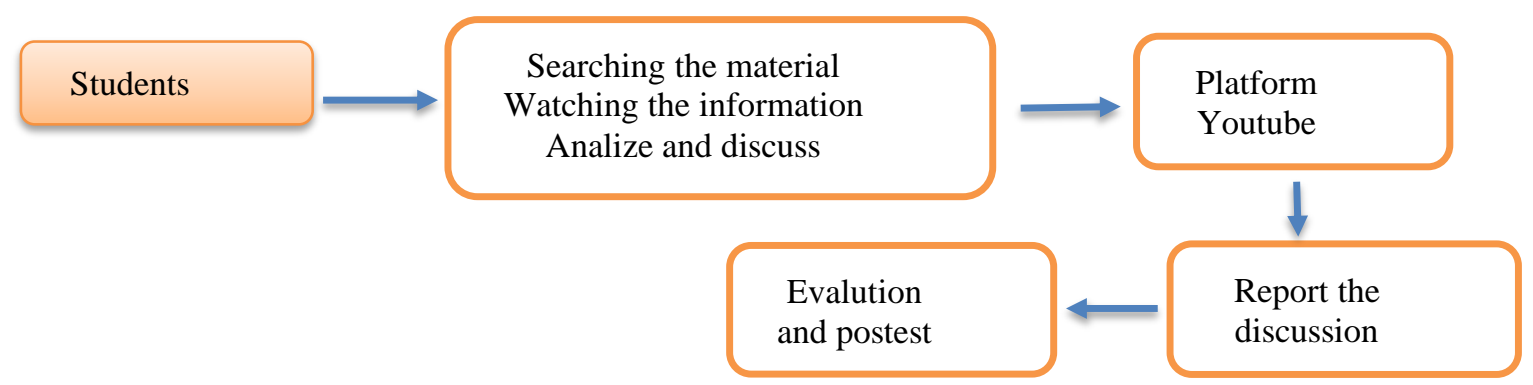

Figure 2. Process of You tube Learning

The use of you tube follows the process of searching for subject matter. The teacher gives initial direction to students, the direction is in the form of a theme or topic to be discussed, while the material to be discussed is about procedure text. Procedure text about making brown sugar boba, 
after getting the link, the students watch you tube making brown sugar boba, then they write, the steps and finally discuss the procedure text. Students can explore procedure text information from several channels or links. Researching the effectiveness of implementing internet teaching applications has the potential to enhance the learning skills of students (Musa, A, et al: 2021). You tube which displays procedure text about brown sugar boba has several choices, but the researcher provides an example link, https://www.youtube.com/watch? $\mathrm{v}=591 \mathrm{dgGBSC}$
Q8.

The preparation of the report is made together (in groups), and can be discussed together. The results of each group are reported to the teacher online. The listening process is obtained when students report the results of the procedure text. The other group listened intently. After reporting they get evaluation and posttest. The posttest is a listening comprehension test. The question is in the form of a procedure text on how to make Es Dalgona Coffee. The following is the data normality test

Table 2. Normality Test

\begin{tabular}{lllcccc}
\hline & \multicolumn{2}{l}{$\begin{array}{l}\text { Kolmogorov- } \\
\text { Smirnova }\end{array}$} & \multicolumn{5}{c}{ Shapiro-Wilk } \\
\hline & Statistic & df & Sig. & Stati stic & df & Sig. \\
\hline Nilai & .089 & 26 & .200 & .977 & 26 & .822 \\
\hline
\end{tabular}

The significance level is $=5 \%$, in the KolmogorovSmirnov (KS) column in table 2 , because $=5 \%=$ $0.05<$ Sig. $=0.200$, then Ho is not rejected. At the significance level $=5 \%$, the Shapiro-Wilk $(\mathrm{SW})$ column in table 2 , because $=5 \%=0.05<\mathrm{Sig}$. $=$
0.822 , then Ho is not rejected. From the Kolmogorov and Shapiro Wilk test, it can be said that, because Ho is accepted, the opinion that the sample data comes from a normal distribution.

Table 3. Homogenitas

Varians Levene

Test of Homogeneity of Variances

\begin{tabular}{lcccc}
\hline & & & & \\
\hline Levene & & & & \\
Statistic & & df1 & df2 & Sig. \\
\hline & .017 & 1 & 48 & .886 \\
\hline
\end{tabular}

The table above shows that the significance level $=5 \%$, in table 3, column Sig. Because $=5 \%=0.05<$ Sig. 0.886 , then $\mathrm{H} 0$ is not rejected, thus, the assumption of homogeneity of variance can be fulfilled.

Table 4 . Paired Sample Statistic

\begin{tabular}{lcccc}
\hline & Mean & N & $\begin{array}{c}\text { Dtd. } \\
\text { oniati }\end{array}$ & $\begin{array}{c}\text { Std. } \\
\text { Error } \\
\text { Mean }\end{array}$ \\
\hline $\begin{array}{l}\text { Pair 1 } \\
\text { sebelum }\end{array}$ & 59.2353 & 35 & 6.1901 & 1.5013
\end{tabular}


In table 4 above, the average value before using you tube is 59.2353 with a standard deviation of 7.1868 , while the value after using the media is 71.5294 , with a standard error of 1.7428 . There is an increase in value of 12.2941 . It can be said that the use of you tube can improve listening comprehension learning outcomes. For this increase in learning outcomes, other factors can still be possible, such as interesting pictures on you tube, neat flow of material and so on (Duffy, P.: 2008).

In Lestari's research. R (2017) stated that the use of you tube. The results of the study show that videos on Youtube can be used as a learning medium, this is also in line with the results of research conducted by Yusri et al. (2018) as a YouTube learning medium to make learning activities for students more focused. Rahmatika et al's : 2021 states that the YouTube learning media is effective in the online learning process. The implication of this research is that Youtube can be used by teachers as a learning medium that can help students learn. The selection of videos presented on YouTube must be adjusted to the material, age, and psychological development of students, making it easier for students to understand the material presented on Youtube. Researchers can say that you tube can contribute as an effective learning media and can improve student learning outcomes. Giving you tube media can improve students' listening comprehension results and that the You Tube had a significant positive effect on perceived student learning (Fralinger, B., \& Owens, R. : 2009). Beside that the function of You tube, it may also be used in order to prompt language learning activities with a focus on specific skills, concepts, or cultura aspects to be reinforced or explored (Brook, J. : 2011). The opinion of other researchers can confirm the function of YouTube in learning is the use of YouTube and TED can be designed to be effective instructional media for Extensive Listening tasks (Saputra, Y., \& Fatimah, A. S., : 2018). The researcher can conlude that you tube can be an effective and reliable learning media, if it can be used in accordance with the correct stages.
The correct use of technological means can also determine student learning outcomes, especially in listening comprehension. The use of you tube media has been able to fulfill the learning of the current century. Students and teachers need information technology skills.

\section{CONCLUSIONS AND RECOMMENDATION}

Based on the description above, it can be concluded that You Tube media can improve comprehension skill outcomes at Alikhlas High School, Bekasi city. There is an increase in value of 12.2941. You tube media learning process includes searching for material, watching and listening to material as well as discussing and sharing material with other students and teachers. The recommendation that can be given is that teachers can try to give students the widest possible time and space so that they can improve their abilities independently, including using YouTube in learning. Consistent evaluation and supervision is one of the keys to successful learning using you tube media. Furthermore, teachers can try to give students the widest possible time and space so that they can improve their abilities independently, including using YouTube in learning. Consistent evaluation and supervision is one of the keys to successful learning using you tube media.

\section{REFERENCES}

Ati, A. P., \& Widiyarto, S. (2020). Literasi Bahasa Dalam Meningkatkan Minat Baca Dan Menulis Pada Siswa Smp Kota Bekasi. Basastra, 9(1), 105-113.

Brook, J. (2011). The affordances of YouTube for language learning and teaching. Hawaii Pacific University TESOL Working Paper Series, 9(1), 2.

Basuki, F. A. (2018). Pemanfaatan Media Digital Untuk Listener Engagement Oleh Media Konvensional: Studi Kasus Media Sosial Youtube Oleh Radio Prambors (Doctoral dissertation, Universitas Multimedia Nusantara). 
Duffy, P. (2008). Using Youtube: Strategies for using new media in teaching and learning. In Enhancing learning through technology: research on emerging technologies and pedagogies (pp. 31-43).

Fralinger, B., \& Owens, R. (2009). You Tube as a learning tool. Journal Of College Teaching \& Learning (Tlc), 6(8).

Febriyanti, R. H., Hadi, I., \& Saputri, N. L. (2018, September). Penerapan penggunaan eclectic method dalam pengajaran bahasa Inggris pada guru SDIT dan SMPIT. In Seminar Nasional dan Diskusi Panel Multidisiplin Hasil Penelitian dan Pengabdian Kepada Masyarakat 2018 (Vol. 1, No. 1).

Hadi, I., \& Liskasaputri, N. (2021). Pelatihan Penulisan Soal Comprehension Questions Para Tutor Berbasis HOTS Bahasa Inggris. Jurnal Pengabdian UntukMu NegeRI, 5(1), 100-106.

Hadi, I., \& Saputri, N. L. (2020). Representation of Social Criticism in the Documentary Film Netflix: Miss Americana. International Journal of Education, Information Technology, and Others, 3(3), 567-573.

Kruse, N. B., \& Veblen, K. K. (2012). Music teaching and learning online: Considering YouTube instructional videos. Journal of Music, Technology \& Education, 5(1), 7787.

Lestari, R. (2017). Pengunaan Youtube Sebagai Media Pembelajaran Bahasa Inggris. Prosiding Seminar Nasional Pendidikan Berkemajuan dan Menggembirakan (The Progressive \& Fun Education Seminar) ke2.

Musa, A., Mohd, N. H., Nurul Ain, C. A., \& Rabiu Mu'azu Musa. (2021). Use of computer technology in the internet using the youtube in teaching and learning student basic technique dances contemporary university of malaysia terengganu. Journal of Physics: Conference Series, 1793(1) doi:http://e-

resources.perpusnas.go.id:2254/10.1088/1 742-6596/1793/1/012032.

Pribadi, B. A. (2017). Media \& teknologi dalam pembelajaran. Prenada Media.
Pramesti, U. D. (2015). Peningkatan penguasaan kosakata bahasa Indonesia dalam keterampilan membaca melalui teka-teki silang (Penelitian tindakan di kelas VI SDN Surakarta 2, Kecamatan Suranenggala, Kabupaten Cirebon, Jawa Barat). Puitika, 11(1), 82-93.

Rahayu, S., Rasmitadila, R., \& Makarim, H. (2018). Penggunan Media Kartu Kata Bergambar Dalam Meningkatkan Kosakata Siswa Down Syndrome. Didaktika Tauhidi: Jurnal Pendidikan Guru Sekolah Dasar, 5(2), 94-105.

Rahmatika, R., Yusuf, M., \& Agung, L. (2021). The Effectiveness of Youtube as an Online Learning Media. Journal of Education Technology, 5(1), 152-158.

Setiadi, E. F., Azmi, A., \& Indrawadi, J. (2019). Youtube Sebagai Sumber Belajar Generasi Milenial. Journal of Civic Education, 2(3), 313-323.

Saputri, N. L. (2021). Analysis of Reading Comprehension Questions Based on Higher Order Thinking Skills in Cognitive Domain Of Revised Bloom's Taxonomy. Jurnal Ilmiah Wahana Pendidikan, 7(2), 27-37.

Saputra, Y., \& Fatimah, A. S. (2018). The use of TED and YOUTUBE in Extensive Listening Course: Exploring possibilities of autonomy learning. Indonesian JELT, 13(1), 73-84.

Supandi, A., Sahrazad, S., Wibowo, A. N., \& Widiyarto, S. (2020). Analisis kompetensi guru: pembelajaran revolusi industri 4.0. Prosiding Samasta.

Widiyarto, S., Wulansari, L., \& Hasanusi, F. S. (2020). Pelatihan "english communicative" guna mempersiapkan sdm berkualitas dan "competitive". Intervensi Komunitas, 1(2), 125-131.

Juita, H. R., \& Widiyarto, S. (2019, March). The Effectiveness of Cooperative Learning Methods: A case study of writing learning at Junior High School. In Second Conference on Language, Literature, Education, and Culture (ICOLLITE 2018) (pp. 266-268). Atlantis Press. 
Widiyarto, S., Damayanti, N., \& Ati, A. P. (2017). Pemakaian Media Scrabbled Dalam Meningkatkan Kemampuan Kosakata Kalimat Dan Keterampilan Menulis Narasi. GERVASI: Jurnal Pengabdian kepada Masyarakat, 1(1), 71-77.

Widiyarto, S., \& Ati, A. P. (2018). Penerapan English communication skill pada siswa SMP. Abdimas Siliwangi, 1(2), 75-80.

Widiyarto, S., Wulansari, L., \& Hasanusi, F. S. (2020). Pelatihan "english communicative" guna mempersiapkan sdm berkualitas dan "competitive". Intervensi Komunitas, 1(2), 125-131.

Yusri, Y., Rosida, A., Jufri, J., \& Mantasiah, R. (2018). Efektivitas Penggunaan Media Youtube Berbasis Various Approaches dalam Meningkatkan Motivasi Belajar Bahasa Inggris. Eralingua: Jurnal Pendidikan Bahasa Asing dan Sastra, 2(2). 